\title{
INFORMAL SECTOR STRATEGY IN URBAN INORGANIC WASTE MANAGEMENT TOWARD 3 M MANAGEMENT (MERUBAH: CHANGING, MENGURANGI: REDUCING, MANFAAT: BENEFIT) IN SEMARANG CITY
}

\author{
Djoko INDROSAPTONO ${ }^{a}$, Joesron Alie SYAHBANA ${ }^{b}$ \\ ${ }^{a}$ Department of Architecture, Faculty of Engineering, Diponegoro University, Jl. Prof. Sudharto SH Semarang, \\ 50275 Indonesia \\ ${ }^{b}$ Department of Urban and Regional Planning, Faculty of Engineering Diponegoro University Jl. Prof. Sudharto \\ SH Semarang, 50275 Indonesia \\ E-mails:indrosaptono@yahoo.com,mr.djokin@gmail.com (corresponding author)
}

Received 31 August 2017; accepted 21 November 2017

\begin{abstract}
Moreover urban waste can be seen as a cultural problem because it affects various aspects of life, and the impact on urban waste management system nowadays are not effective and efficient yet. The reason for conducting this research is the emergence of the informal sector phenomena of urban waste management that can contribute to reduce the volume of urban waste production. The purpose of this research is to find out the informal sector strategy in urban waste management, especially inorganic waste. The researchers used qualitative research to explain the phenomenon as the focus of research.

The result of research is $3 \mathrm{M}$ phenomenon, that is derived from Indonesian words (Mengubah = Changing, Mengurangi= Reducing, Manfaat = Benefit), in the management of urban inorganic waste. The explanation are; Mengubah: turning waste into economic value; Mengurangi: If the economic value of the urban waste volumes increases, the volume of urban waste will eventually be reduced; and Manfaat: the benefits obtained are management cultivating empowerment, reducing the burden of the landfill volume, being closer to inorganic zero waste condition.

Suggestions are as follows: [a] development of management towards go-green, [b] urban waste management based on predictable community empowerment will be more effective and efficient in the future.
\end{abstract}

Keywords: strategy, informal sector, management, inorganic waste, urban, 3 M (Mengubah = Changing, Mengurangi= Reducing, Manfaat = Benefit).

\section{Introduction}

Stated in Act no 18th 2008 (Undang-Undang RI No.18, 2008) in several major cities in Indonesia, garbage collection, transport and disposal services are carried out by the Special Sanitation Department for waste management. In fact the problem of waste is still crucial. Even garbage can be seen as a cultural problem because it affects various aspects of life, especially in big cities like Jakarta, Semarang, Surabaya, Bandung, Palembang and Medan. Urban waste management is one of the key subsystems of urban metabolism, which significantly affects the various lifes that exist within (Zhou et al. 2015). Research in Beijing City by optimizing the developed waste management system can not only predict the amount of waste generated by the city in the future, but also reflects the dynamic, interactive, and uncertain characteristics of the ongoing waste management system (Dai et al. 2011). Urban Wastewater Management System (UWMS) that is proposed can accommodate various indicators referring to socio-economic performance and environmental impact (Chifari et al. 2016). Urban waste management is implemented by the formal sector (City Government) with centralization-decentralization system, which is the transportation from the source of waste to the garbage dump and ends in the landfill, is relatively good. In reality there are still many obstacles, especially the volume of waste as the number of urban population increases. The modeling system synergizes the analysis and tools, can certainly provide an opportunity to develop better waste management strategies toward conformity and encourage future perspectives for waste management and government agencies in the EU (Pires et al. 2011). A study that describes the 
involvement of stakeholders and at the same time sensing the internal and external conditions of waste management in Shenzhen, with SWOT identification, can be useful for developing and promoting future waste management constructs at the strategic level (Yuan 2013). Besides that, in practice, it is still not optimal because many factors such as habits of Indonesian people who mostly still throw the garbage not in its available place, and the care to keep cleanliness in public places also still low. In this case they assume there is an officer who handles it (Indrosaptono et al. 2016). On the other hand the requirement for landfill (Final Disposal Site) increases. Therefore, the government always prepares the extension of the landfill location and even cultivating new wider land. To search for new land, there are obstacles like both the provision of a large budget and the refusal of citizens around because it is related to environmental problems. Therefore, an effective, systematic and integrated urban waste management solution is needed to involve all stakeholders (Indrosaptono et al. 2016). Urban waste management is an element of environmental governance which is considered as sustainable development. This condition can be achieved when the volume of waste and final disposal can be controlled (Mesjasz-Lech 2014). As a developing country, population growth in Indonesia has increased and its production reaches 190,000 metric tons / day by 2014. Selection of appropriate technology is needed to reduce the volume of waste and use waste as energy (Sudibyo et al. 2017). According to ITN-BUET (2004), in the management of waste in urban areas, there are 3 (three) managers namely; formal sector (city), informal sector, and community initiative. The informal sector of urban inorganic waste management has a very simple and informal organization, initially from frequent meetings in the job of sorting out waste that still has resale value, which results can be used as daily life hangers (Indrosaptono et al. 2016). Actually, the organization forms a chain of mutual binding which perform such management activities and it is required good cooperation. Technical operational of the informal sector of urban inorganic waste management, consists of: (i) Scavengers, have the task of directly sorting out garbage in waste source such as; (ii) Collectors, whose duty is to collect temporary collection of the scavengers by way of giving the cost / service fee according to the type of garbage / rub obtained as agreed, (iii ) Mayeng (Scavenger or Collector) bring waste direct to the factory, (iv) Processing Plant (private formal sector), as the last recipient of scavengers, collectors and waste factory which the result to be processed again become ready-made goods (Fig. 1) (Indrosaptono et al. 2016). Mayeng is a Javanese terminology which means the activity's subject (Indrosaptono et al. 2016). The phenomenon of the emergence of the informal sector of inorganic waste management in urban areas that have contributed to reduce the volume of urban inorganic waste as much as $48 \%$ equivalent to 290 tons per day, allegedly due to the abundance of urban waste production volume, and waste management of municipal governments has not been effective (Indrosaptono et al. 2016). The informal sector workers have a very simple way of thinking, the most important thing is that they can get income (money) with their simple skill and capacity in order to sustain their life. The need for a place to be used is as an economic activity, they are tenacious soul to sustain life. The informal

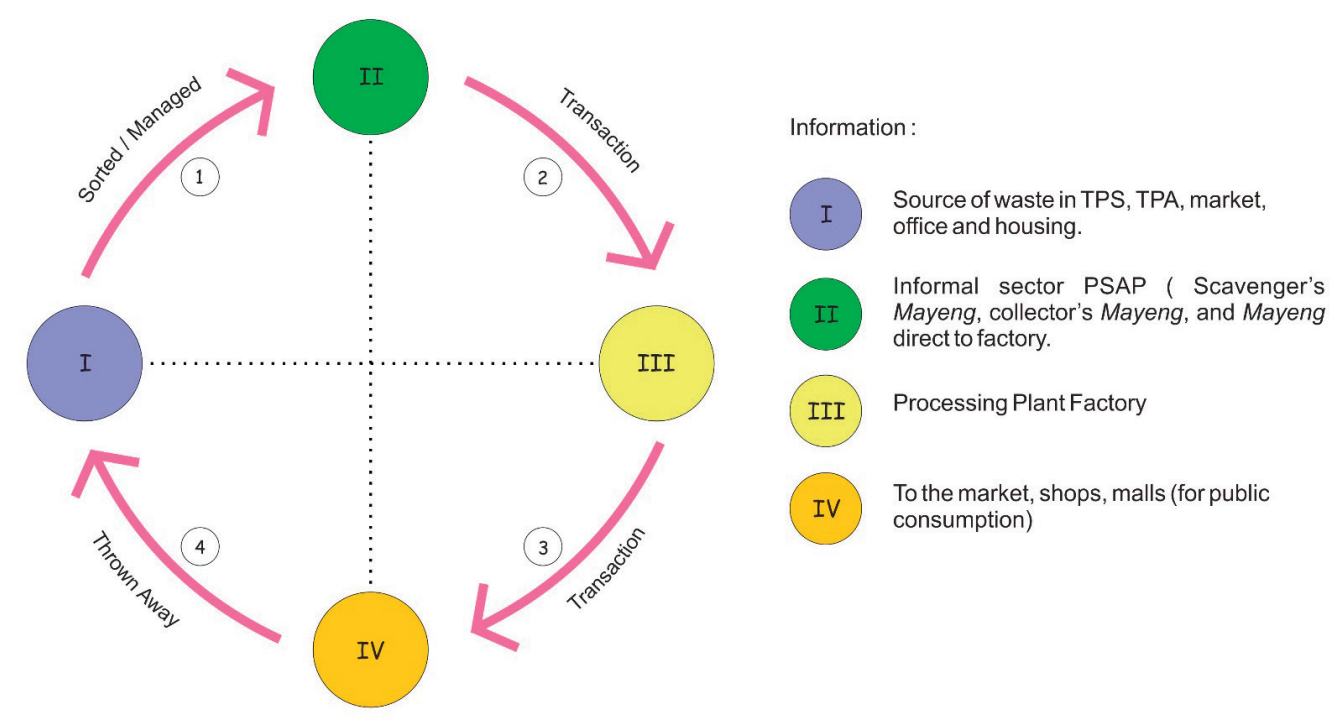

Fig. 1. Informal Sector of Anorganic Waste's Management System 
sector workers have low quality of work and prioritize their physical capacity (Amaral, Quintin 2006). The informal sector workers have an effective strategy of adaptability in urban environments (Perera, Amin 1996). The role of "the informal waste sector" is active in areas not served by formal sector waste management, in addition to the demands of living costs (Aleluia, Ferrão 2016). Sorting and garbage collection activities of economic value are carried out in places they deem to meet the criteria. Based on ISO 14001, small and medium enterprises (SMEs) includes the informal sector of waste management like the ones India that show the target of effectiveness in the management (Singh et al. 2015). The concept of integrated city waste management, by integrating plastic and paper recycling processes, is carried out using the process optimization approach (Satchatippavarn et al. 2016). Looking at its development from 2000 until now, the informal sector activities of urban inorganic waste management still survive. This condition is indicated by the expansion of "place of socio-economic transactions" as a container of activities that are considered to provide as a hanger of his life. Theoretical perspectives show the vastness of informal economic research in different domains and at the same time is useful as a basis for future entrepreneurial research (Webb et al. 2013). In fact, the national economic determinant factor is the informal sector (Thai, Turkina 2014). NonGovernmental Organization (NGO) cooperation, and local government, with focus on processing, recycling and user costs can be achieved efficient urban waste management (Mohan et al. 2016). The greater the volume at the landfill with no special attention and concrete actions by the municipal government will significantly result in uncontrolled greenhouse gas emissions (Menikpura et al. 2013). In many countries, zero waste programs evolve through programs, plans, policies and strategies. In practice, it is applied without a holistic zero waste strategy (Zaman, Lehmann 2013). The need for sustainable public education programs on the prevention of waste production and reuse (recycling) as the right solution for Nigeria (Ezeah, Roberts 2012).

The increasing volume of inorganic garbage transactions resulted in the emergence of new transaction places in the old city of Semarang which is considered appropriate as the carrying capacity of the management. In this case, the target places are abandoned city building units, the building units that have been less or no longer considered by the owner or the city government such as building units in the Old Town area of Semarang. To understand and explain, it is necessary to have deep understanding of the empirical facts on the phenomenon. Therefore, this study attempts to answer some questions as follows [1] what are informal sectorial strategies for urban inorganic waste management towards $3 \mathrm{M}$ management? The empowerment or role of the informal sector in the management of inorganic waste in urban areas shows rapid growth, as the indicator always adds or expands the "place of transaction" as a place of activity. Considering the facts in the fields, questions come up; [2] what are driving factors for the growth of management activities? Growing and developing management is a social phenomenon in which have interaction between human-individual interactions with the individual; individuals with groups; and groups with groups in performing activities in a place either in space or outdoors. Some studies of the informal sector of urban inorganic waste management are relatively small and tend to address only part of the section such as; on some models of the management system only, some proposed regulations in the form of management system policies related to funding and management places arranged by the city government (top-down system), so that has not been a comprehensive the discussion.

The purpose of this research is to know the informal sector strategies in the management of urban inorganic waste toward the management of $3 \mathrm{M}$ in Semarang city. A practical benefit as feedback aims to provide inputs to city managers that are useful for predicting eco-friendly and effective management.

\section{Method}

Semarang City was chosen as the case in this research, of course with various considerations. The considerations are as follows;

- First, Semarang city is the capital city of Central Java province,

- Second, Semarang city in its development has obtained awards related to achievements in the field of hygiene and urban planning. The awards were given four times in a row by the central government like "Adipura" award, which in this case is not owned by other big cities. Besides that, it also received an award related to traffic order and transportation, namely the award "Wahana Tata Nugraha" obtained three times.

- Third, the management of municipal waste infrastructure in Semarang already has a municipal landfill. The role of landfill is very important in accommodating urban waste production in all the garbage dumps in Semarang city area to next twenty years. Urban waste management systems use centralization-decentralization as other big cities do.

The next step was to locate the locus, by doing a thorough observation first after it was selected whether 
it had completeness of the phenomenon according to the research focus. In determining the locus, it is required purposive sampling (Iskandar 2008). If the locus had the completeness of the phenomenon in accordance with the focus of research, the next step was to do a deep observation. The in-depth observation was done in order to find research units. The next step was dividing the locus into three units of observation based on the specific characteristics of a particular phenomenon. The division of this observation area aimed to facilitate the discovery of certain specific features in observation units. The focus of the research in Semarang city was in three units of observation, namely (1) Landfill, collectors (informal sector) in Banyumanik sub-district, (2) Final disposal site / landfill of Jatibarang city, and (3) Storage at Jl. Suari, Jl. Garuda in old city / Bubakan Semarang (Fig. 2). The reasons for determining the units of observation were selected by the actors as informal sector workers with the following classification: [i] inorganic waste management activities as the main mainstay because they want to subsistence (urbanization) or life hangers, [ii] employment (prime age), low education, wages earned relatively below minimum wage, [iii] unskilled and most migrants, [iv] limited, only to the procurement of employment opportunities and generate direct income for themselves, [v] characteristics relatively uninvolved enterprises, high skills, relatively easy to do by various community groups and at low risk, [vi] the absence of long-term contractual relationships, thus able to ease acceptable labor in these activities.

To determine or choose a good resource person, among others, (a) they have been long enough and intensive together in the activities undertaken; (b) they are fully engaged with such activities or fields; (c) they have enough time for information, (Alisjahbana 2006).

The selection of informants using snowball techniques is the best technique in qualitative research, especially research on sensitive topics or populations that are difficult to reach. The basic strategy of snowballs starts with a key informant, scavenger who has a relatively long working life of about twenty years, located in Banyumanik area after a gradual or processed interview, researchers assigned one to two key informants Pak Trs as "collector" who started his 1975s work at Banyumanik location, one from Purwodadi and one from Boyolali. After the interview, the information obtained was still considered not enough, the researchers then asked for suggestions and directions to them who should be the next informants who have the experience, knowledge, and information.

Finally, one of the key informants of Mr. Sbr who they call "Direct Factory" is located at Suari Street, Old City / Bubakan Semarang. Early 1975s, urban inorganic waste management activities have been going on until now, means having experience for \pm 37 years and the origin of these informants are from Purwodadi, after the interview, researchers obtained important information in a trace and very complete both experiences and knowledge they have during their activities. Because all the required information was considered sufficient, the researcher stopped to search for information. The larger or more complete acquisition of information obtained in sequence from the first, second, third and fourth key informants in qualitative research is referred as the snowball technique.

The data obtained and collected in this study are qualitative data from observation, interview and doc-

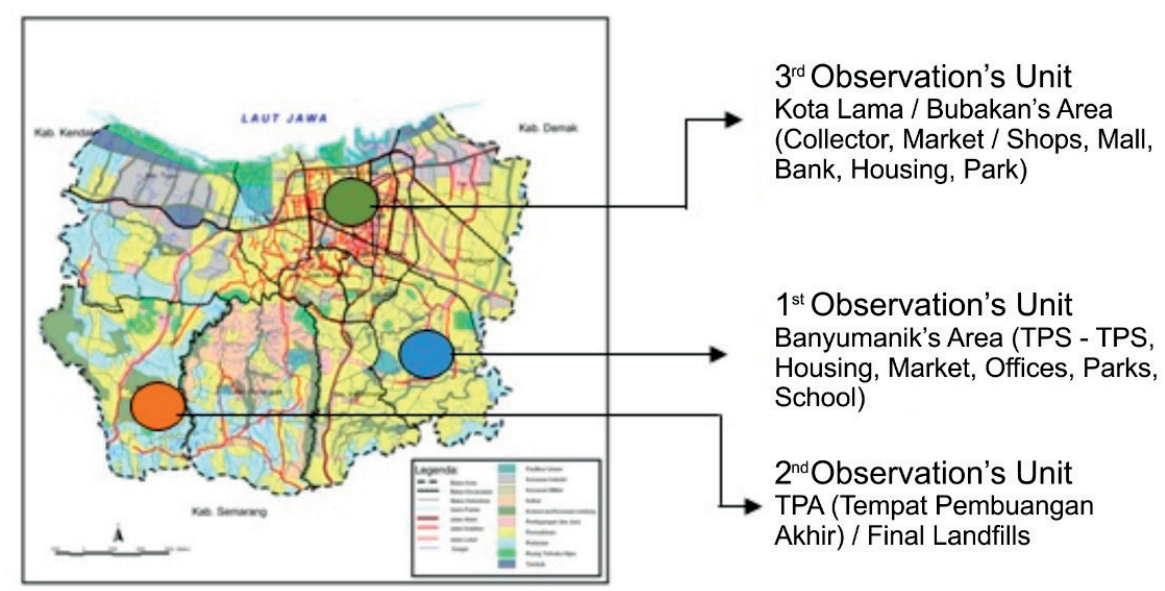

Fig. 2. $1^{\text {st }}, 2^{\text {nd }}, 3^{\text {rd }}$ Observation Unit 
umentation. In this case, the focus of observation leads to three main components, namely: space, actors and activities. During the research process, a researcher must blend and act as a key instrument, because it is necessary to analyze the ability to describe it further, and more importantly construct the social interaction into a solid strategy / concept of meaning. The steps taken to obtain the purity of the phenomenon are as follows:

a) Approach to $\mathrm{Mr}$. Sbr urban inorganic waste management was in various ways. During the process approach, researcher tried to be present in their midst, both when they were transacting and when they were doing other activities. To obtain valid data, researcher tried to open themselves by introducing themselves slowly as well as carrying used stuffs for sale, in this case trying to appear in a simple way to look really need money and live mediocre. Basically researcher was trying to be low profile so, not seen as someone who was revealing their activities. Further interviews were conducted. In the interview process was done at the time of transactions, especially when weighing and determining the purchasing price, with a little casual conversation of humour after receiving the money from the sale. The atmosphere of interview discussion was very open, responsive, and spontaneous. It sometimes felt timeless, so it was difficult to stop the conversation because the position of the researcher is like his friend. His full disclosure through stories was about the good and the disillusionment both internally and externally, though they still seemed very enthusiastic in their efforts. The establishment of this good relationship strengthened their level of confidence in the researcher, so that this condition the researcher could directly explore various data needed, and at the same time the researchers could recheck the data that have been obtained from $\mathrm{Mr}$ Trs about urban inorgaik waste management before. If the researcher had the opportunity to assist the activity, in this condition the researcher could feel the work load that must be done by him. In addition, it could observe various things that happen, such as buyer characteristics, pricing based on merchandise, and types of goods and merchandise that have high selling value. Researcher also often follows $\mathrm{Mr} \mathrm{Sbr}$ urban inorganic waste management when deposit or sell to processing factories using heavy truck transport mode of 20 tons. At the same time researcher made observations, photographed the way loading and unloading until the settlement and payment process with the employee of the factory. During the process of loading and unloading the researcher could see the good relationship between $\mathrm{MrSbr}$ and the processing factory employees, this condition was shown how the handling and acceptance was different from other managers. Conducting interviews with parties consideed by them as driving figures (backbone) sustainability of urban inorganic waste management. Interviews with those perceived as characters are much easier than other garbage managers, because they feel they are getting discussions for exchanging ideas, or exchanging opinions, or even hesitating to ask the researcher for the various strategies they have been working on.

b) After obtaining information from informants of in organizing urban inorganic waste, researcher also conducted interviews with city government staff (Municipal Government), especially urban waste management staff who directly manage the municipal waste both at the municipal, sub-district, and district levels, final disposal of the city (Landfill). In each interview, the researcher always avoided formal interviews, strived to create an informal, natural atmosphere (without recording or using other recorders), and focused on informants to express their experiences over the years.

c) Documentation technique. Documents derived from the municipal government were relatively easy for the researcher to obtain because they were available, in contrast to the data derived from the Urban Inorganic Waste Management community archive, it should be able to ensure that the archive can be kept confidential, and promised not to open or tell whoever or it would be detrimental to the Urban Inorganic Waste Manager.

d) Then identifying and classifying fixed data in various situation and condition. Analysis is in qualitative research by making description and interpretation (Strauss, Corbin 2007). Through the way of interpretative understanding, it is expected to facilitate researchers to directly make the classification and identification of data acquisition in the field. In this activity, the recording of data and information by using field notes, done as soon as possible after the in-depth interview 
took place, for example in the workplace they transact. Furthermore, from the results of observation, behaviors in the form of actions that occured were sorted out for further deepening through in-depth interviews so that it could obtain meaning and understanding. Evidence of the validity of the data is determined by the credibility of the findings and its interpretation by seeking the findings, and the interpretation is done in accordance with actual conditions and it is approved by the research source, (Moleong 1994).

\section{Discussion}

\section{Results}

The results of the $3 \mathrm{M}$ management of the informal sector in urban inorganic waste management can contribute positively to reduce the volume of waste generated from the urban community by $48 \%$ to 290 tons from the volume of 603.3 tons. In this case, it directly benefits the formal sector urban waste management system that has been done. The emergence of this strategy begins when the demand for inorganic waste (rosok) as raw material for the factory can be reproduced into readymade production. The increasing demand for inorganic volume of inorganic waste each year poses a challenge for the informal sector community to manage it. Rosok (informal community community term) or inorganic waste as the raw material of the factory in question is waste that can still be processed again (recycle) such as; paper / cardboard, plastic and iron / metal whose existence tend to blend into one with the waste of urban community production. The key to the continued management of $3 \mathrm{M}$ is the informal sector because of good relationships with the factory which in this case is based on mutual trust. This means that the informal

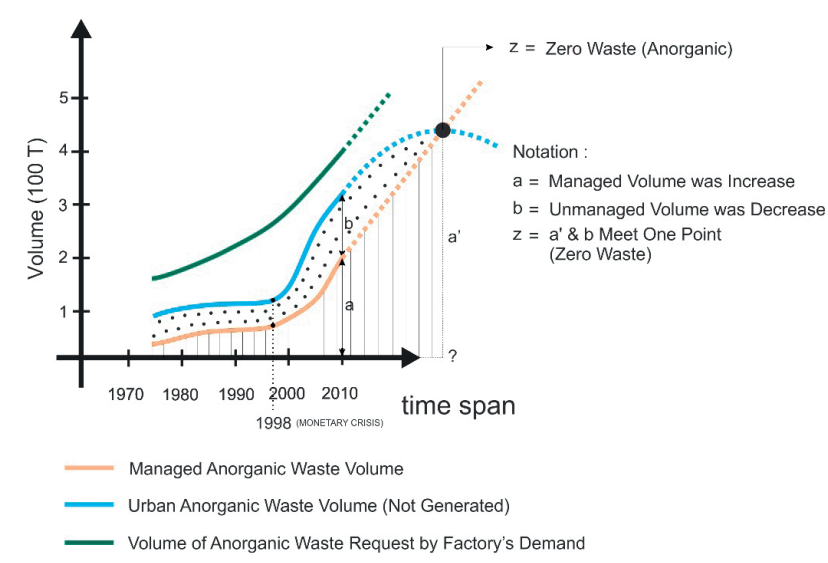

Fig. 3. The Informal Sector of Managed Anorganic Waste was increase sector keeps the quality of inorganic waste deposited in accordance with the requirements requested by the factory, as well as the factory in terms of determining the purchase price and time of payment. The informal sector in its management uses the strategy; (i) change; (ii) reduce; and (iii) benefits, with the following explanation; turning waste into economic value, meaning it contains an element of cost performance reward for anyone who does it. The amount or amount of the value of the received fee is very dependent on the results obtained, thus the value of the benefits received depends on the level of physical ability. The strategy of determining the value of the cost benefits associated with the performance results will encourage to improve the results obtained. It is one strategy to encourage performance for individuals and groups of the informal sector to get results as much as possible. If this condition persists continuously it will help to reduce the volume of urban waste production, which in turn can benefit for informal sector communities such as obtaining a fixed income that can be used for working capital and living expenses (Fig. 3). Greater benefit is to help reduce the load volume capacity of landfill (Disposal Place) Semarang city. In a certain period, if the larger volume of inorganic waste (rosok) managed by the informal sector, this will directly give benefits like; (i) the value of money received by the informal sector is greater; (ii) the volume of unorganized urban inorganic waste is decreasing, so it can be predicted that inorganic zero waste can be achieved (Fig. 4).

\section{The 3 M Maintenance Management Process (Changing, Reducing, Benefit)}

The phenomenon begins with the continuous demand of inorganic waste as a raw material of the factory, this condition becomes a challenge for the informal sector to implement some strategies in urban inorganic waste

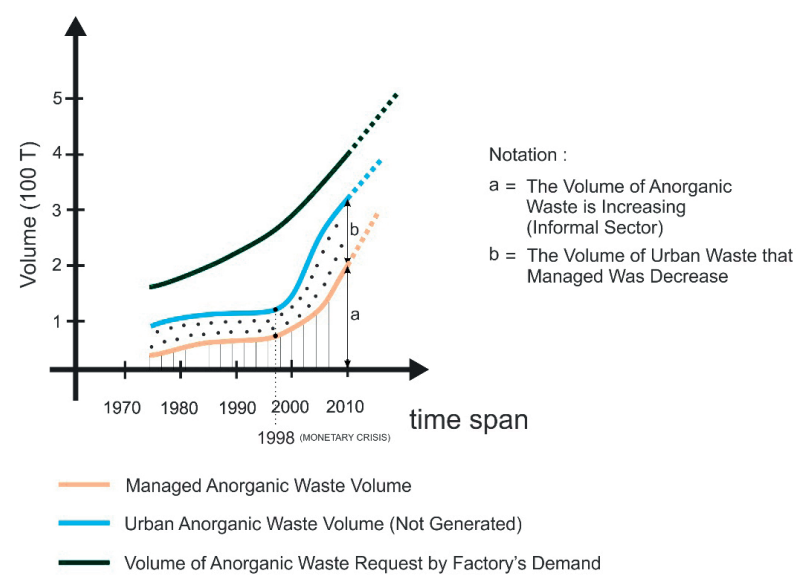

Fig. 4. The Prediction of Anorganic Zero Waste Achievement 
management. As for some of these strategies are as follows:

a) Strategic Place of Transaction Management

In place of management Suari street, Kepodang street and Garuda street, old town area of Semarang every day of inorganic garbage (rosok) selling \pm 50 tons of various types such as; plastic, cardboard / paper, and metal / iron. When converted with the value of rupiah for \pm Rp. 40,000,000 (forty million rupiah). The informal sector community (Collector and Scavengers) comes from various parts of Semarang city, even some coming from outside Semarang city (Fig. 5).

b) Strategy of Place Management as Attractiveness (Magnet)

The place applies the system of purchase price of inorganic waste is higher than the price set elsewhere. The service in the process of weighing up more payments is in priority, it aims to provide satisfaction for its customers.

c) Strategy of Place Management as "Motor" Sustainability Management

The proceeds from the sale of inorganic waste from the processing plant are not only used to meet the needs of their families, but also for the sustainability of urban inorganic waste management. In this case, it prioritizes the purchasing service for the informal sector communities who sell it. If the management can still take

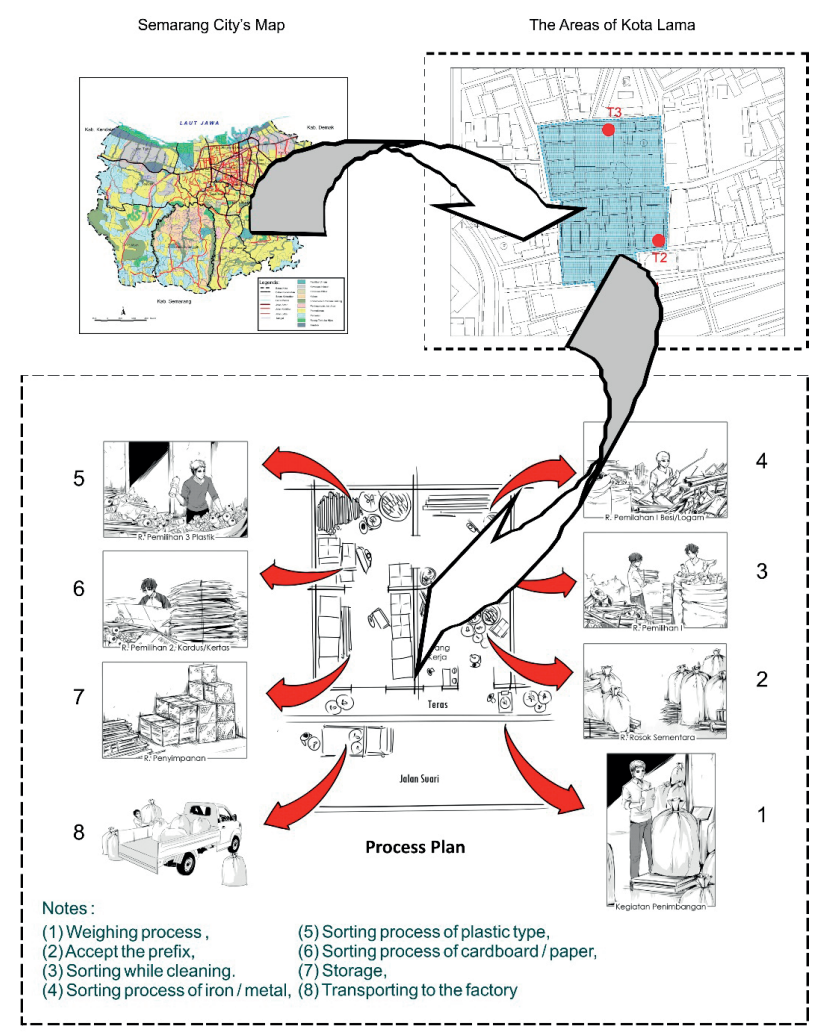

Fig. 5. The Space Layout for Informal Sector Activities place, it also provides a livelihood for the informal sector community of urban inorganic waste management.

d) Strategy of Place Management causes Togetherness

The hierarchy of responsibilities in the management, especially the procurement of costs is in the form of an inverted pyramid (Fig. 6). For example, if a scavenger is at level one, it will be the responsibility of a Collector who is on the second level, and who is in the second level will be the responsibility of Direct Factory on level three, so it can be said that the higher level is the greater to have responsibility for managing the procurement of the costs required for the lower levels.

Although management takes place in a hierarchy of responsibilities, they need each other in a process which means that if one process does not fill or move will interfere with another process. It can be said when all levels (levels) filled or move the management process will run effectively and efficiently. The establishment of togetherness can be realized because of the embedded social system among them from childhood to adulthood. Togetherness in the social system embodied in behavior when conducting inorganic waste management activities such as; (i) the sense of kinship, (ii) the spirit of work and honesty, and (iii) the existence of the fighting power to obtain employment.

e) Strategy of Understanding the Needs of the Informal Sector

One of the efforts in order to cultivate and encourage interaction of buying and selling of inorganic waste is by giving "down payment" to the waste collectors with certain criteria. "down payment" is a cash aid given ahead of work. A pure "down payment" with no special requirements such as; interest, repayment deadline, collateral, and soon they must deposit the waste, it means the refund is not in the form of money but in the form of goods and preferably trust each other and understand the obligations that must be fulfilled .

f) Emergency Strategy

Buying activities with a "bangkel" system is to buy or sell inorganic waste in relatively large quantities with the

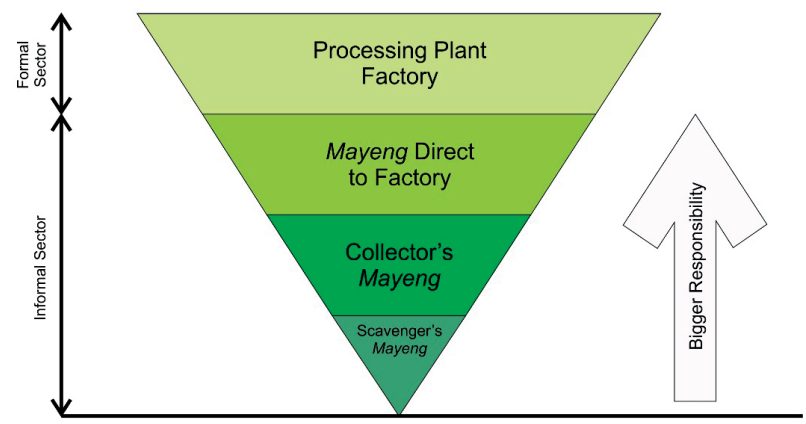

Fig. 6. Responsibility Hierarchy 
value of the price according to the agreement in which the profit has been calculated although relatively small. Sell-purchase with a system of "bangkel" is usually done between Jump Factory and The collectors. The buying and selling interactions can take place when there is a request for those who need or have an interest. Demand for bangkel can happen because there are several reasons such as; (i) before it is time to sell / deposit to the factory or the processing factory requires a sudden cost, (ii) feel enough of the results they have earned. The nature of buying and selling with a "bangkel" system is preferable to mutual assistance, especially to cover the need for cost (money) in case of disaster or problems.

g) Junkyard Strategy as a Money-Generating Capital

In the management of inorganic waste (rosok) urban areas, junkyard becomes the main place, because the volume of large storage area is directly proportional to the economic value obtained. Besides that, the junkyard has the flexibility of storage volume that can adjust the needs. In place selection as "junkyard", we should pay attention to some considerations such as;

(i) Utilization of Displaced City Building Units

Ready-to-use building units are preferred with relatively simple physical condition in the hope that the purchase price or lease is relatively affordable. Physical condition is not an important priority that is important to fulfill the function as a junkyard. Preferred or intended building units are often found in the Old Town / Bubakan Semarang. Building units that are not in use or left empty by the owner.

(ii) Large Capacity Building Needs

Inorganic waste containers (rosok) large capacity becomes the main needs. A large junkyard here means that it can be a junkyard with a certain volume capacity or comprises several junkyards with twice larger for

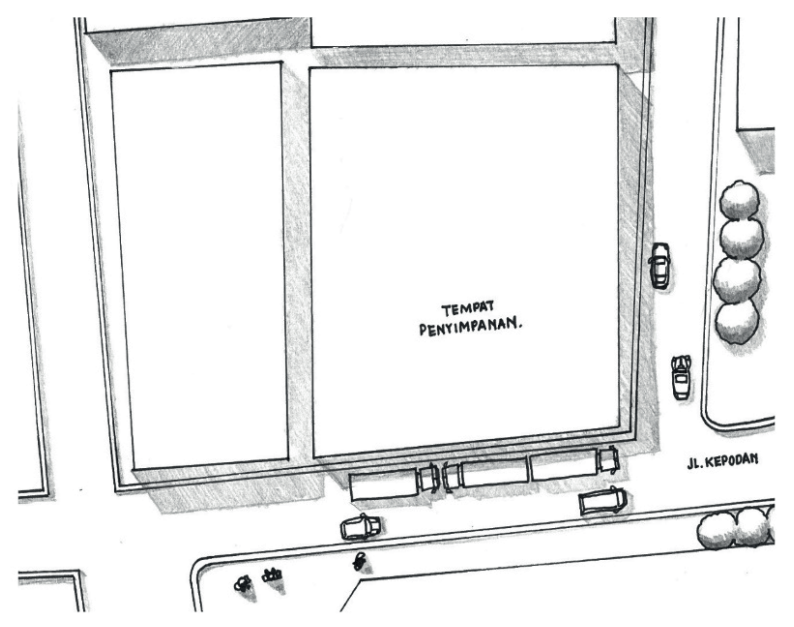

Fig. 7. The Bird View of Road Infrastructure as the Logistic Supporting Aspect at Suari Street, Kota Lama Semarang volume capacity. The building units in city / Bubakan average have the same relative capacity, because the building units of the Dutch era relics are relatively large (two-floors) (Figs 7-10).

(iii) Expansion Prospects of Supply Places

Inorganic waste management site (rosok) urban area in Old City / Bubakan have a great opportunity to expand or add new junkyard. The availability of empty and less well-maintained building units in the old city / Bubakan area provides a great opportunity to be used as an expansion in anticipation of increasing urban waste production every day.

(iv) The smoothness of the transport mode in loading and unloading

Different types of transport modes (pickup trucks, large trucks, large trucks) are large, can be easily accessible and provide circulation clarity to the junkyard in the city / Bubakan. In addition, the condition of road width in the junkyard is relatively wide, so it functions the circulation of various types of vehicles, still have enough space when use for loading and unloading (Figs 7-10).

From the above description, the following propositions are formulated as follows:

- Increased demand for commodity volume of raw materials processing and availability of large quantities of commodities and large capacity places encourage the development of an informal inorganic waste business / commodity business.

- The more facing the challenge of transforming urban waste production into economic value, the stronger the urban inorganic waste business community / business.

- The greater the volume stored in place and the supply of inorganic waste to the processing plant as raw material, the greater the benefit for the society and the urban environment.

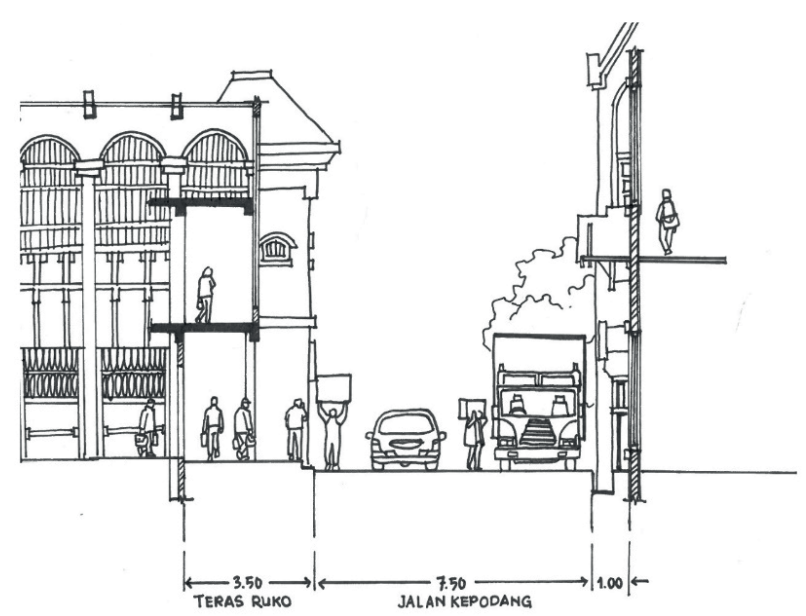

Fig. 8. The Building Facade Condition of The Social-Economic Trading Activities at Suari Street, Kota Lama Semarang 


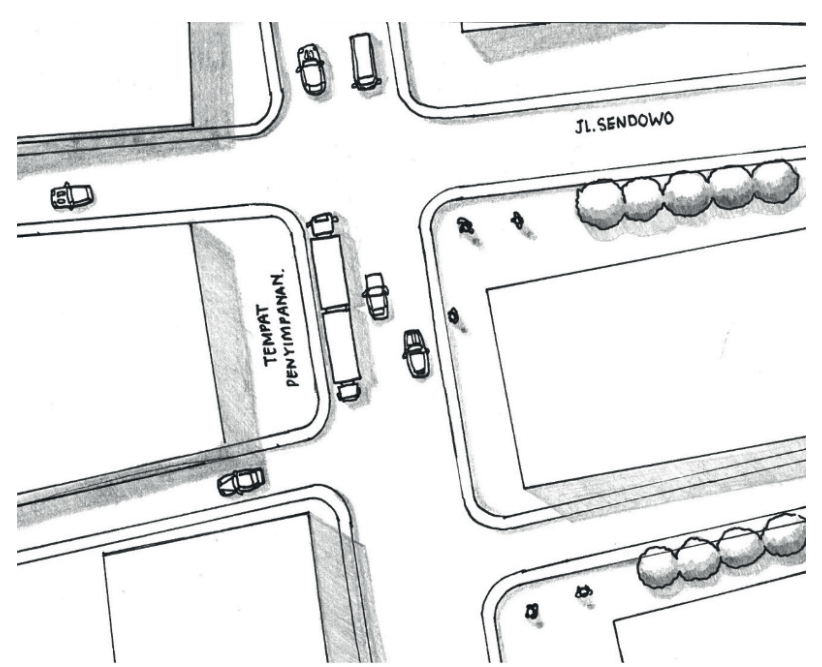

Fig. 9. The Bird View of the Situation at Kepodang Street, Kota Lama Semarang Where There are many Activities

The growth and development of urban informal sector business / business in it contained strategies such as; (1) Dare to face challenges, (2) Utilize Opportunity, (3) Have ability, (4) Beneficial for social and environment. Therefore, the informal sector can be regarded as an entrepreneur, when it is very good at managing, it can grow and improve the results while maintaining the sustainability of the management (ref). Strategy has always had the latest innovation to be able to maintain the quality and quantity to be achieved as planned (ref). The propositions are as follows:

- The stronger the entrepreneurial spirit of urban inorganic waste business and the role of place as the carrying capacity, the stronger the potential prospective management of $3 \mathrm{M}$ (Change, Reduce, Benefit).

\section{Conclusions}

In conclusion as well as suggestions for implementing the management are as follows: [a] Development of Strategy of Management towards Go-Green, [b] Urban Waste Management Based on People's Empowerment.

a. Development of an Eco-Friendly / Go-Green Management Strategy

3M Management (Changing, Reducing, Benefit) has given positive results, it can reduce the volume of municipal waste. In addition it can provide various benefits. One of the supporting factors is the place where transactions are always the source of life for the informal sector community. Especially the place as a management center is as the center of various informal community interactions. The management center is located in the Old City, Semarang by utilizing abandoned urban building units. The situation and condition of the building unit meet the desired criteria. The infor-

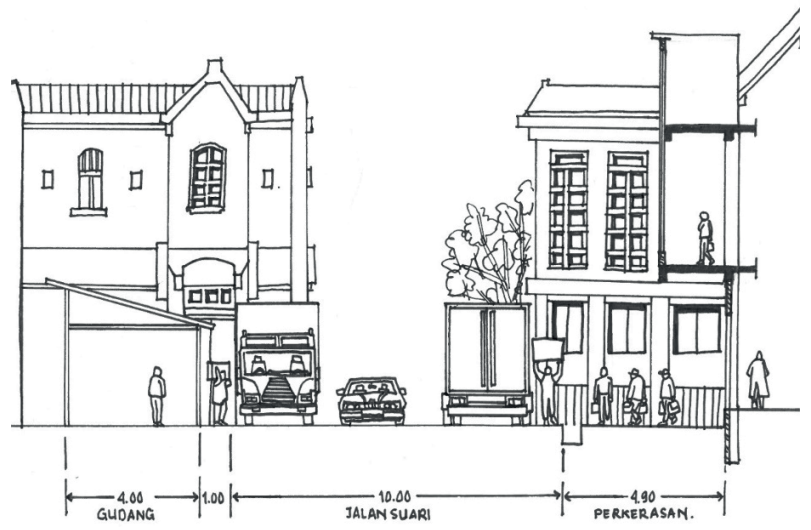

Fig. 10. The Building Façade of the Meaningful Place at Kepodang Street, Kota Lama Semarang

mal sector in urban inorganic waste management has not received any intervention from the parties, in this case help / donation such as the provision of funds and facilities and infrastructure. Despite the soul of independence, when they are offered help, they are also willing to accept. Therefore, short-term advice is the government to be able to assist the operational funds and in the procurement of the transaction place. Assistance from government will increase the acceleration of inorganic volume of managed waste increasing rapidly, and unorganized inorganic waste is reduced. Means if the increased volume of inorganic waste is managed, management towards go-green can be fulfilled.

a. Urban Waste Management Based on Community Empowerment

3M Management (Changing, Reducing, and Benefiting) in the informal sector has fostered empowerment and togetherness in making a living. It has shown a positive result over the time, in this case the increased volume of inorganic waste managed, and vice versa decreasing inorganic urban waste that has not been managed. Inorganic waste management is increasing in volume, because the economic value factor offered is very interesting and the time to get it relatively quick. Means if urban organic waste can be treated the same as inorganic waste that has adequate selling value, it can be estimated to have the same position as well. And if it can be developed into a new management system, it will certainly provide benefits both for the community and urban waste management. With this model system, the people are able to calculate for themselves how much profit obtained, because of the economic value of the trend can change a person's behavior to obtain a better life. 
Changing waste of economic value will have a positive effect on waste generators everywhere despite the slow changes. It will foster the empowerment of changing behavior that formerly they throw away the garbage, they will save it instead. In addition, it can be predicted that new waste managers will emerge, it means opening of new alternative employment opportunities. Thus, urban waste management systems based on community empowerment can be predicted in the future will be more developed effectively and efficiently.

Thanks to the Dean of Faculty of Engineering, Diponegoro University, Chairman of the Department of Architecture Faculty of Engineering, Chairman of Doctorate Program and colleagues who have helped and encouraged me to finish this manuscript.

\section{References}

Aleluia, J.; Ferrão, P. 2016. Characterization of urban waste management practices in developing Asian countries: a new analytical framework based on waste characteristics and urban dimension, Waste Management 58: 415-429. https://doi.org/10.1016/j.wasman.2016.05.008

Alisjahbana, 2006. Marginalisasi Sektor Informal Perkotaan. Surabaya: ITS Press.

Amaral, P. S.; Quintin, E. 2006. A competitive model of the informal sector, Journal of Monetary Economics 53(7): 1541-1553. https://doi.org/10.1016/j.jmoneco.2005.07.016

Chifari, R., et al. 2016. A holistic framework for the integrated assessment of urban waste management systems, Ecological Indicators. https://doi.org/10.1016/j.ecolind.2016.03.006

Dai, C.; Li, Y. P.; Huang, G. H. 2011. A two-stage support-vector-regression optimization model for municipal solid waste management - a case study of Beijing, China, Journal of Environmental Management 92(12): 3023-3037. https://doi.org/10.1016/j.jenvman.2011.06.038

Indrosaptono, D.; Buchori, I.; Syahbana, A. J. 2016. Peran sektor informal dalam pengelolaan sampah anorganik di kota Semarang: Disertasi Program Doktor Teknik dan Perkotaan Fakultas Teknik Universitas Diponegoro Semarang.

Iskandar. 2008. Metodologi Penelitian Pendidikan Sosial (Kuantitatif dan Kualitatif). Gaung Persada Press Jakarta.

ITN-BUET. 2004. Country Paper Bangladesh, in SAARC Workshop on Solid Waste Management, 10-12 October 2004, Dhaka, Bangladesh.

Ezeah, C.; Roberts, C. L. 2012. Analysis of barriers and success factors affecting the adoption of sustainable management of municipal solid waste in Nigeria, Journal of Environmental Management 103: 9-14

https://doi.org/10.1016/j.jenvman.2012.02.027

Menikpura, S. N. M.; Sang-Arun, J.; Bengtsson, M. 2013. Integrated solid waste management: an approach for enhancing climate co-benefits through resource recovery, Journal of Cleaner Production 58: 34-42. https://doi.org/10.1016/j.jclepro.2013.03.012

Mesjasz-Lech, A. 2014. Municipal waste management in context of sustainable urban development, Procedia - Social and Behavioral Sciences 151: 244-256. https://doi.org/10.1016/j.sbspro.2014.10.023

Mohan, G.; Sinha, U. K.; Lal, M. 2016. Managing of solid waste through public private partnership model, Procedia Environmental Sciences 35: 158-168. https://doi.org/10.1016/j.proenv.2016.07.066
Moleong, L. J. 2002. Metodologi Penelitian Kualitatif, Cetakan ke: XVI, remaja Rosdakarya, bandung, Muhadjir, Noeng, 2000, Metodologi Penelitian Kualitaatif, edisi V, Rake Sarasin, Jakarta.

Perera, L. A. S. R.; Amin, A. T. M. N. 1996. Accommodating the informal sector: a strategy for urban environmental management, Journal of Environmental Management 46(1): 3-15. https://doi.org/10.1006/jema.1996.0002

Pires, A.; Martinho, G.; Chang, N.-B. 2011. Solid waste management in European countries: a review of systems analysis techniques, Journal of Environmental Management 92(4): 1033-1050. https://doi.org/10.1016/j.jenvman.2010.11.024

Satchatippavarn, S., et al. 2016. Urban biorefinery for waste processing, Chemical Engineering Research and Design 107: 81-90. https://doi.org/10.1016/j.cherd.2015.09.022

Singh, M.; Brueckner, M.; Padhy, P. K. 2015. Environmental management system ISO 14001: effective waste minimisation in small and medium enterprises in India, Journal of Cleaner Production 102: 285-301.

https://doi.org/10.1016/j.jclepro.2015.04.028

Strauss, A.; Corbin, J. 2007. Dasar-Dasar Penelitian Kualitatif: Tatalangkah dan Teknik-Teknik Teoritisasi Data (Terj,). Penerbit Pustaka Pelajar, Yogyakarta.

Sudibyo, H., et al. 2017. Technological evaluation of municipal solid waste management system in Indonesia, in Energy Procedia: 263-269.

https://doi.org/10.1016/j.egypro.2017.03.312

Thai, M. T. T.; Turkina, E. 2014. Macro-level determinants of formal entrepreneurship versus informal entrepreneurship, Journal of Business Venturing 29(4): 490-510. https://doi.org/10.1016/j.jbusvent.2013.07.005

Undang-Undang Republik Indonesia No. 18 Tahun 2008 tentang Pengelolaan Sampah.

Webb, J. W., et al. 2013. Research on entrepreneurship in the informal economy: framing a research agenda, Journal of Business Venturing 28(5): 598-614. https://doi.org/10.1016/j.jbusvent.2012.05.003

Yuan, H. 2013. A SWOT analysis of successful construction waste management, Journal of Cleaner Production 39: 1-8. https://doi.org/10.1016/j.jclepro.2012.08.016

Zaman, A. U.; Lehmann, S. 2013. The zero waste index: a performance measurement tool for waste management systems in a "zero waste city", Journal of Cleaner Production 50: 123-132. https://doi.org/10.1016/j.jclepro.2012.11.041

Zhou, C., et al. 2015. Modeling the carbon cycle of the municipal solid waste management system for urban metabolism, Ecological Modelling 318: 150-156. https://doi.org/10.1016/j.ecolmodel.2014.11.027

\section{DJOKO INDROSAPTONO}

Senior Lecturer, Assoc. Prof at Architecture, Diponegoro University (UNDIP), Majors: Behavioral Architecture, Urban Design and Urban Management.

\section{JOESRON ALIE SYAHBANA}

Senior Lecturer, Assoc. Prof at Architecture and Planning, Diponegoro University (UNDIP), Majors: Community Based Urban Planning, Urban Management, Qualitative Research Methods. 